\title{
Jewish Theatre in Poland as an Institution of Nationality, Education and Intercultural Dialogue
}

\author{
Agata Katarzyna Dąbrowska \\ Department of European Studies, Faculty of International Relations and Political Studies, Lodz University, \\ Poland, adabrowska@uni.lodz.pl
}

\begin{abstract}
The aim of the paper is to discuss the function of Jewish theatre in Poland ${ }^{l}$ as an institution promoting the knowledge of the Jewish culture and tradition and stimulating intercultural Polish-Jewish dialogue through ages. It focuses on the theatrical activities and their intellectual, social, political and cultural contexts. It shows relevance of the theatre's works for academic researches and institutional structure for the study of East European Jewry. Finally, it discusses the impact of the Jewish theatre on the identity of the local Jewish communities, analyzing the creation of theatre's self-image as cultural and educational institution in various historical periods.
\end{abstract}

\section{Keywords}

Anti-Semitism; intercultural dialogue; Jews in Poland; theatre; Yiddish culture; war.

\footnotetext{
${ }^{1}$ This term refers in this article only to Jewish theatres performing in Polish and Yiddish language.

This is an Open Access article distributed in accordance with the Creative Commons Attribution Non Commercial (CC-BYNC-ND 4.0) license, which permits others to copy or share the article, provided original work is properly cited and that this is not done for commercial purposes. Users may not remix, transform, or build upon the material and may not distribute the modified material (http://creativecommons.org/licenses/by-nc/4.0/)

DOI: 10.22618/TP.PCMS.20164.349011
} 


\section{From shund to art: breaking stereotypes}

Analysing cultural life in Poland, it is impossible to ignore the role Polish Jews played in it. ${ }^{2}$ However for centuries, their culture has been marginalised, which greatly influenced the way the Jewish art was perceived. The average people thought it artistic kitsch, and as its greatest achievement they thought its least valuable form - the theatre called shund [Yiddish: "rubbish"]. This negative estimation had several reasons. First, the performances in Yiddish were dubbed "the rubbish ghetto art" 3 or "art in jabber" 4 and their artistic values were contested. Secondly, Jewish theatrical troupes were systematically fought with by the Polish groups whose interests they endangered. Thirdly, the opponents of the Jewish theatre claimed that, instead of promoting good manners, it aroused wild instincts in people. The outraged reviewers reported that viewers, the majority of which consisted of the poor people, forced their way into the theatres, quarrelled about the seats and were eating food during spectacles. There were also frequent interventions of police to regain control over the outraged crowd. That was how the premiere of Abraham Goldfaden's Shulamis (1897) ended in the Selin's Garden in Łódź. The maddening crowd has beaten the cash-desk clerk then, battered caretakers, trampled flower beds and broke up boards in the fence. ${ }^{5}$

In the face of such a strong aversion towards the Jewish theatre, its reformers introduced William Shakespeare's dramas into the repertoire. The decision was caused by the fact that the works of the English bard were included into the world classical literature and the theatres which performed them were regarded ambitious. The first Shakespearean drama staged in a Jewish theatre in Poland was Hamlet. Its premiere took place in 1913 in Łódź and was very important for the development of both professional and Shakespearean Jewish theatre since it was the first adaptation of this drama in Yiddish in Central and Eastern Europe. ${ }^{6}$ The spectacle was prepared by the team under the management of Nachum Lipowski and Juliusz Adler and was directed by Rudolf Zaslawski, ${ }^{7}$ who also starred the leading role. The performance evoked a huge interest both of the audience and critics. In numerous reviews published in Lodzer Tageblat ${ }^{8}$ and Najes Lodzer Morgenbla. $t^{9}$ The management of the theatre was praised for the repertoire policies which enabled an ordinary Lódź resident to get to know one of the most important masterpieces of the world culture. And the role of Hamlet ensured Zaslawski enormous popularity and belonged to his iron repertoire. It is worth noting that while 1913 marked the end of the epoch of stars in the Polish Shakespearean theatre, the Jewish theatres were just entering that stage. Beginning with the Lódź premiere up to the outbreak of the Second World War, the Shakespearean characters were played by outstanding Jewish artists and their creations made them

\footnotetext{
${ }^{2}$ For centuries, Poland was home to the largest and most significant Jewish community in the world. In 1939 around 3,500,000 people declared Jewish nationality. The contemporary Polish Jewish community is estimated to have approximately 20,000 members.

3 Anonymous, "Co o nas piszą," [What is written about us] Izraelita 42 (1905): 494.

${ }^{4}$ Anonymous, No title, Izraelita 8 (1886): 60.

${ }^{5}$ Anonymous, "Koło," [Circle] Izraelita 22 (1897): 8.

${ }^{6}$ Z. Zylbercweig, "Rudolf Zaslawski," in Leksikon fun jidiszn teater vol. 1 [Lexicon to Yiddish theatre], ed. Zalmen Zylbercweig (New York: Jidishe aktiorn jiunie in Amerike 1931), 751-752.

${ }^{7}$ Rudof Zaslawski (1886-?, born Rojben Leib Zasławski) - Jewish actor and theatrical director.

8 L. Kahan, "Hamlet ojffirung in Scala teater," [The performance of Hamlet in the Scala theatre] Lodzer Tageblat 292 (1913): 4; Z. Chan, “Hamlet af jidisz," [Hamlet in Yiddish] Lodzer Tageblatr 118 (1913): 2; Z. Chan, "Der erszter Hamlet af der jidisze bine. R. Zaslawski in Adlers teatrer," [The first Hamlet on the Yiddish stage. R. Zasławski in Adler's Theatre] Lodzer Tageblat” 120 (1913): 4.

${ }^{9}$ A. Mukduni, “A derklerung," [Exptanation] Najes Lodzer Morgenblatr 126 (1913): 3.
} 
internationally famous. For instance, the role of Othello made Juliusz Adler ${ }^{10}$ an idol of American youth while a display of Abraham Morewski's talent in Hamlet generated admiration for him in Germany and Russia.

Introducing Shakespeare dramas into Yiddish stages did not only contribute to break the negative image of the theatre but also revealed the creativity of Jewish artists. In contrary to Polish artists, Jewish directors more frequently used not original versions of Shakespearean plays but their adaptations expanded with references to Jewish history and tradition. A good example of this kind of productions is The Jewish Hamlet ${ }^{11}$ by Izydor Zolotarewski ${ }^{12}$, The Jewish Othello ${ }^{13}$ by Leon Kobrin. ${ }^{14}$ In these works, authors referred to the heritage of the English bard making Jews the protagonists of his dramas. The most popular play of this kind was Der Jidiszer Kenig Lir [The Jewish King Lear] ${ }^{15}$ by Jacob Gordin. ${ }^{16}$ It was frequently performed in Jewish theatres in Poland and the title role was played, among others, by Moryc Szwarc, Jerzy Woskowski and Jakub Zilbert. One of the most famous performances took place in 1919 in Cracow. Nowy Dziennik thought it to be a success thanks to excellent creations of the actors of the Cracow Jewish Theatre.

The title role was created by Mr Jungwirth, who has prepared himself thoroughly for this role. The best moment came when he was mad with pain torn by despair. He showed a masterly excellence in Act Three, in shocking tragic scenes of internal struggle. He, the magnate who, by his own fault, became a beggar, rushes out to the street like a wounded bull to look for people more merciful than his uncaring daughter. The only details which spoiled the effect were his suppurating eyes which generated not sympathy but certain distaste. Jungwirth had an appropriate partner in Mr Liebgold playing Shamay who - in Act One - evoked spontaneous bursts of laughter and then, unless he overreacted, he played a sensitive and faithful servant

\footnotetext{
${ }^{10}$ Adler successfully performed Othello in the Panteon Thetre in Lublin in February 1917.

${ }^{11}$ The drama also known under the title Der Jesziwe Bocher [The Yeshive Student].

${ }^{12}$ Izydor Zolotarewski (1875-1945), actor, translator and dramatist; he was born in Ukraine but was conducting his creative activities in America; he is the author of numerous dramas the protagonists of which are fallen women who usually are prone to charms of their Christian heartbreakers and pay for it dearly. M. Bułat, "Es gibt nit beser in der welt...a jidisze mame. Postać matki w wybranych utworach Abrahama Goldfadena, Józefa Latajnera, Izydora Zołotarewskiego i Jakuba Gordina," [There is no one better in the world...Yiddish mother. The figure of mother in selected dramas of Abraham Goldfaden, Józef Latajner, Izydor Zołotarewski and Jacob Gordin] in Nieme dusze?: Kobiety w kulturze jidysz [Silent Souls?: Women in Yiddish culture], ed. Joanna Lisek (Wrocław: Wydawnictwo Uniwersytetu Wrocławskiego 2010), 346.

${ }^{13}$ The drama also known under the title Blind musician or Jewish Othello.

${ }^{14}$ Leon Kobrin (1873-1946) - translator, novelist and playwright; he created his works under the influence of Jacob Gordin; author of several dozen dramas. Their actions usually take place in confined Jewish communities Z. Zylbercweig, "Leon Kobrin," in Leksikon fun jidiszn teater vol. 4 [Lexicon of Yiddish theatre], ed. Zalmen Zylbercweig (New York: Jidishe aktiorn jiunie in Amerike 1963), 2962-3044.

${ }^{15}$ The Jewish King Lear is based on the Shakespearean tragedy. The play begins during the Purim holiday. The title character, David Mojszele, a rich Vilnius merchant, gives expensive presents to his relatives. His youngest daughter, Tajbele, is the only one who refuses to accept the gift. She turns out to be insubordinate to her father and hence, he orders her to be chased away from their house. Then, David informs the members of his family that he intends to make his property over to his daughters and leave for Palestine to study the Torah. He is warned of the dangers of such risky decision by Jaffe, reminding him of King Lear's fate. However, Mojszele ignores the precious advice. After his return from Palestine, he is beaten and chased into the street where he is forced to beg. "Give a handout to a new beggar. Give a handout to a new King Lear." Finally, he visits a synagogue where he meets Tajbele who forgives him and provides him with shelter and care.

${ }^{16}$ Jakob Gordin (1853-1909) - publicist, playwright and translator writing in Yiddish. He wrote and translated from foreign languages over a hundred dramas. Some of them were filmed. Zylbercweig, "Jacob Gordin," in Leksikon fun jidishn teater vol. 4, 392-461.
} 
Duved, creating a very interesting character. Mr Urich showed a lot of intelligence in some scenes and Ms Brueh was an excellent Tabele. Mrs Jungwirth, Mr Weissbrot and Mr Erlichman lacked dramatic expression. Mrs Urich had some good moments, particularly in Act Three. ${ }^{17}$

The adaptation was a success but the reviewer recommended moderation in stage solutions which were, in his opinion, excessive. ${ }^{18}$

Following the success of Shakespearean productions more dramatic works of European canon were introduced into Yiddish stages making them a very important educational institution. It is worth to mention that before the First World War most of the Jewish boys received only traditional education limited to Torah studies. Therefore Jewish theatre became one of the most important tools for obtaining secular and liberal knowledge.

Foundation of professional theatres encouraged Yiddish activists to start a campaign that Jewish culture should not only entertain or educate but it should also service in national needs. According to Icchok Lejb Perec it was "a path to a renewed Jewish national vision." 19 Jonas Turkow, Zygmunt Turkow or Jecheskiel Mojsze Najman believed that Jewish theatre, performing not in other languages but only in Yiddish, could become a powerful medium for creating and representing Jewish nation. ${ }^{20}$

\section{Polish-Jewish dialogue}

Contrary to brothers Turkow's and Najman's vision was Andrzej Marek. ${ }^{21} \mathrm{He}$ founded one of the first Jewish theatres performing in Polish language. His artistic endeavour garnered positive and negative responses. He was accused of spreading blasphemy and instigation to national riots just after his premiere of Golem. ${ }^{22} \mathrm{He}$ was perceived as a traitor and a convert by the orthodox Yiddish circles. Despite of these attacks Marek accepted political consequences of his works and kept developing his artistic philosophy during the whole interwar period..$^{23}$

\footnotetext{
${ }^{17}$ Anonymous, “Z teatru żydowskiego. Żydowski Król Lir. Obraz życiowy w 4 aktach J. Gordina,” [The Jewish theatre. The Jewish King Lear. The drama in 4 acts by J. Gordin] Nowy Dziennik 171 (1919): 3.

${ }^{18}$ The Nowy Dziennik critic wrote: „As far as the performance itself is concerned, we think that it in the interest of serious plays ad artists to avoid brutal exaggerations, jokes in the most serious situations and to give up all extra additions and severe abuse (e.g., pushing the blind Lear off the chair, etc.) The stage lights should be slightly dimmed. The management should try to arrange a few decorations since only amateurs can tolerate the action to take place in the same miserable room although the play was acted for over five years and in different venues. Ibid.

${ }^{19}$ Chone Shmeruk, Peretses yiesh-vizye [Perec's vision of despair], (New York: YIVO, 1971), 13-14.

${ }^{20}$ J. Turkow, "Jidisz teater on jidisz," [Yiddish theatre about Yiddish] Literarisze Bleter 33 (1929): 641; J. Turkow, "Di 'kemfer' far jidiszer kultur," [The fighter about Yiddish culture] Literarisze Bleter 36 (1929): 1-2; J. M. Najman, “Der gojlem po polsku,” [Golem in Polish] Hajnt 128 (1928): 9.

${ }^{21}$ Andrzej Marek (1879-1943, born Marek Arenstein) - Yiddish and Polish playwright and theatre director. He wrote several plays (i.e.The Eternal Story and Singers) and translated them into Polish. Polski stownik judaistyczny, tom 2 [Polish Judaic dictionary], ed. Zofia Borzymińska, Rafał Żebrowski (Warsaw: Prószyński i spółka, 2003), 105-106.

${ }^{22}$ Anonymous, "Di oyffirung fun H. Leyviks Gojlem in lubliner pojliszn sztot-teater," [The performance of Goylem by H. Leyvik in Polish Municipal Theatre in Lublin] Literarishe Bleter 3 (1928): 61.

${ }^{23}$ Michael Steinlauf, Polish-Yiddish theater: the case of Mark Arnshteyn: a study of the interplay among Yiddish, Polish, and Polish-language Yiddish culture in the modern period (Ann Arbor: UMI Dissertation Service, 1988), 230-300.
} 
Of the particular importance in the Jewish theatrical history in Poland was the adaptation of $D i$ jidisze kenigin Lir, oder Mirele Efros [The Jewish Queen Lear, or Mirele Efros], prepared by Marek in 1929. The director gave the production an educational character. He translated the drama from Yiddish and staged it in a Polish theatre to make Poles acquainted with the world canon of Jewish literature. "That drama initiated my systematic activities aimed at making the Polish society acquainted with soul and life of Jewish nation" - the artist said in an interview for the Lódź Republika. "I devote my whole life to that idea and I feel I am not wasting it!." ${ }^{24}$ Mirele Efros's adaptation had one more superior purpose. It was one of the stages of the mission, which Marek set up for his Jewish theatre, namely, to reconcile Polish and Jewish nations.

In the theatre I wish to be not only a director but a citizen as well. During the war, every man is obliged to be a soldier, during peace, everybody should fight for peaceful co-existence of nations and races, for goods of culture and for justice. I am fighting for these ideas in the theatre as a playwright, author of adaptations and director! ${ }^{25}$

Marek's opinions and his mission were received by Jewish milieus gathered around Nasz Przeglad with approval. The newspaper even promoted the thesis on the right of Jews to create not only in Yiddish but also in Polish.

The skilful hand of Andrzej Marek provided us with a new type of the Jewish theatre: the Polish-Jewish theatre, performing Jewish dramas in Polish. Performances of this type have been so far sporadic. There is no theatre yet, not the permanent troupe and nor regular shows but this type has been accepted and there is nothing against its stabilising [...] Mr Marek has fulfilled his task perfectly. He created the team with the help of which the entire Jewish theatre can be run in Polish. And such theatre is very much needed and it can co-exist with the Yiddish theatre like Polish-Jewish periodical co-exists with the Jewish press. ${ }^{26}$

Marek's adaptation aroused enormous interest of the audience also due to its cast. The leading role in The Jewish Queen Lear was performed by Wanda Siemaszkowa. Certain of the unique value of Gordin's female protagonist she even made an attempt at directing that drama in Vilnius. This premiere attracted a very diversified audience. There were Poles but also "old Jewish women in wigs," Helena Zelwerowicz recalls, "who were moved to tears."27

However, Mirele Efros directed both by Marek and Siemaszkowa revealed political and ideological divisions of the Polish nation. For instance, the circles close to the National Democracy used the spectacles as a pretext to present their anti-Semitic views. On the occasion of the premiere in Vilnius, the reviewer of the nationalistic Dziennik Wileński began his deliberations with the words "I do not like Jewish plays." 28 The critic of Gtos Narodu was asking: "Why the Krakow audience was forced to endure boring and tearful rhapsody?." He also inquired what made Wanda Siemaszkowa play the title role. That play, according to the reviewer hand neither literary values nor theatrical values and could

\footnotetext{
${ }^{24}$ Ego., "Przed premjerą Miry Efros. Rozmowa z Andrzejem Markiem," [Before the premiere of Mirele Efros. An interview with Andrzej Marek] Republika 169 (1929): 4.

${ }^{25}$ Anonymous, "Mirele Efros na polskiej scenie," [Mirele Efros on Polish stage] Chwila 3711 (1929): 5.

${ }^{26}$ Zastępca, "Scena polsko-żydowska," [Polish-Jewish stage] Nasz Przeglad 203 (1929): 6.

${ }^{27}$ M. Kozłowska, Wilno teatralne [Theatrical Vilnius] (Warsaw: Ogólnopolski Klub Miłośników Litwy, 1998), 160.

${ }^{28}$ T. Pilawa.," Mirla Efros, sztuka w 4 aktach J. Gordina," [Mirele Efros, play in 4 acts by J. Gordin] Dziennik Wileński 287 (1929): 10.
} 
only serve as a source of knowledge of "the racial base and the values entirely Jewish" which were limited exclusively to financial matters. ${ }^{29}$ "Aryans have certain emotional areas which exclude the matters of money; they feel a certain shame in face of money," concluded the reviewer pointing to differences between Poles and Jews. "They feel certain repulsion and a certain aversion. Here [in the Jewish community] money is a titbit, ornamentation and a flower of life." ${ }^{\prime 3}$ The most fervent opponent of staging Mirele Efros, a Jewish play in Polish theatres was a critic of Myśl Narodowa warning of "the true black (gabardine) invasion." ${ }^{1}$

\section{Spiritual therapy}

Anti-Semitism escalation in Europe led to the outbreak of the Second World War, which, contrary to the plans and common expectations of the Nazis, did not end up with a quick collapse of Jewish culture. Various kinds of informal events, such as theatrical performances, musical concerts, and poetry readings were organised in private houses. The cultural entertainment was also provided by cafeterias, nightclubs and workplaces. However, most of these theatrical and musical activities were illegal because they were organized without the Nazi permission. ${ }^{32}$

This situation changed in the 1940's. At that time many representatives of Jewish intellectual circles, including writers, poets, actors, musicians, stage designers and directors were detained in the ghettos all over Poland. They eagerly tried to continue their pre-war artistic activities. Particular role in that difficult reality was played by the Jewish theatre for which very high moral demands had been set up. It was to be a form of spiritual therapy for the ghetto audience tired of life in the difficult ghetto conditions.

In 1941-1942, in the Warsaw ghetto alone, five open theatres were functioning with the consent of the Nazi. Three of them played in Yiddish and two in Polish. The largest one was Nowy Teatr Kameralny [New Chamber Theatre], which functioned from July 1941 until the liquidation of most of the ghetto a year later. Michał Znicz was its leading actor and Marek directed all the spectacles. The repertoire of Nowy Teatr Kameralny was rather ambitious and consisted of dramatic works of Jewish and European canon while other theatres such as the cabaret-style Femina, Eldorado, Teatr na Pięterku and the Melody Palace staged mostly light and humorous revues consisting of a series of short sketches, songs, and dances. ${ }^{33}$

According to Gazeta Żydowska during 20 months ghetto theatres performed around 68 premieres and their artistic character was sometimes questioned. Henryk Czerwiński, in his article of a meaningful title "Szmira" [Kitsch], lamented over the situation. The critic inquired straightforwardly: "Is there really no different repertoire and should we feed the audience with so miserable spectacles?" Finally, he stated that a Jewish spectator is probably delighted with the so-called "folk operettas with dancing, singing and the happy end." 34 Such severe estimation of the stage activities in ghettos was

\footnotetext{
${ }^{29}$ F.O., "Z Teatru Bagatela,” [From the Bagatela Theatre] Głos Narodu 53 (1930) 4.

30 Ibid.

31 J.Z., "Nauka i literatura. Więcej godności, poeto!," [Science and literature. More dignity, poet!] Myśl Narodowa 19 (1934): 286.

32 M. Steinlauf, Theatre, http://www.yivoencyclopedia.org/printarticle. aspx $9 i d=298 \&$ print=auto (accessed September 30, 2015).

${ }^{33}$ R. Sakowska, Ludzie z dzielnicy zamkniętej - z dziejów Żydów w Warszawie w latach okupacji hitlerowskiej: październik 1939-marzec 1943 [People from the closed district - from the history of Jews in Warsaw during the Nazi occupation: October 1939-March 1943] (Warsaw: PWN, 1993), 121-128.

${ }^{34}$ H. Czerwiński, “Szmira, ” [Kitsch] Gazeta Żydowska 107 (1941): 3.
} 
opposed by Gita Ejzenzwajg writing that theatres were "in miserable conditions," without subsidies, help and with starving actors. ${ }^{35}$ Their role was not to take care of artistic values but to manifest that Jewish culture has survived. So, the repertoire was selected in the way to adapt to tastes of general public. $^{36}$

The Nazis permitted also one Yiddish theatre to open in Lódź ghetto. The Avangarde Theatre performed mainly kleynkunst repertoire several times a week under the direction of Mosze Pulawer. However, the role of this theatre is questionable. Some critics hold the view that it was a kind of tool to glorify Chaim Rumkowski, the President of the ghetto. It is evidenced by the fact that any form of satire or parody, criticizing Rumkowski or the Nazi authorities, were removed from performances. ${ }^{37}$

Totally different character from stages in Łódź and Warsaw ghetto had Jewish theatre in Vilnius ghetto. "The first performance in January 1942, was preceded by a bitter polemic dimaxed by the appearance of leaflets with the slogan, "Af a besojlem szpilt men nit kejn teater" [One does not play theatre in a cemetery]" ${ }^{\prime 3}$. Ghetto residents were aware that thousands of Vilnius Jews had been murdered in the nearby Ponary Forest over the previous six months. That is why most of the performances were dedicated to the war victims. A great example of such an event was the premiere of Mirele Efros. The adaptation had, first of all, a patriotic character. It was preceded by a piano concert of Fryderyk Chopin's music and songs by the cantor Idelson and Liuba Lewicka. ${ }^{39}$

\section{Theatre marked with mass graves and crematoria}

Although the overwhelming majority of the ghetto actors and audiences were murdered during the Holocaust, Jewish theatres managed to continue a kind of afterlife in the post-war Poland. Since October 1944 Jewish cultural life began to revive. First concerts, stage shows and individual performances were organised and they gave an evidence of the permanence and immortality of the national heritage of Polish Jews. The concert of the Warsaw ghetto survivors, Diana Blumenfeld and Jonas Turkow had a symbolic meaning. They presented the programme under the title Pieśn uszła cało [The Song Has Survived] at the Municipal Theatre in Lublin. It stirred up a great emotion among the audience. ${ }^{40}$

During the first concert, Diana with swollen legs and wearing a claret and red robe, was singing a Jewish song. The listeners were the people whose hearts seemed to have dried out $[\ldots]$ The theatre was packed with Jewish wanderers, the people who

\footnotetext{
${ }^{35}$ Life conditions of the actors performing in ghettos were difficult. They were employed on contracts in a few institutions. Many of them were starving since their income was low and irregular which was also the result of low ticket prices. They were not paid permanent wages for their work but shared profits from performances with the remaining theatre employees. In this situation, the best evidences of admiration for starving actresses were not flowers but food which they received from delighted fans. Barbara Engelking, Jacek Leociak, Getto warszawskie. Przewodnik po nieistniejacym mieście [The Warsaw Ghetto: A Guide to the Perished City] (Warsaw: IFiS PAN, 2001), 539.

${ }^{36}$ Ibid, s. 540.

${ }^{37}$ J. Frenkiel, "Teatr i inna działalność artystyczna w getcie łódzkim," [Theatre and other artistic activity in the Łódź ghetto] in Łódzkie sceny żydowske [Lodz Jewish scene], ed. M. Leyko (Łódź: Wydawnictwo Uniwersytetu Łódzkiego, 2000), 97-108.

${ }^{38}$ Steinlauf, Theatre.

${ }^{39}$ Jagoda Hernik-Spalińska, Życie teatralne w Wilnie podczas II wojny światowej [Theatre life in Vilnius during the Second World War] (Warsaw: Instytut Sztuki Polskiej Akademii Nauk, 2005), 234.

${ }^{40}$ Sz. Gąssowski, "Teatr w latach 1944-1949" [Theatre in years 1944-1949] in Państwowy Teatr Żydowski im. Ester Rachel Kamińskiej [The Ester Rachel Kamińska State Jewish Theater], ed. idem (Warsaw: PWN, 1995), 100.
} 
yesterday had no right to live. The theatre was bursting at the seams. The mood was solemn. One might think a kind of a mystery play was being performed. As soon as Diana managed to utter the first words in a trembling voice, the audience burst into sobs which came right from the bottom of their souls. The clogged source which seemed to be dried out for so long had suddenly gushed out with a great strength. This concert became the beginning of the newly emerging Jewish stage after the years of deluge. ${ }^{41}$

That evening was meant to prove that the pre-war cultural life of Polish Jews was beginning to revive. The Central Committee of Polish Jews founded on 15 November 1945 also thought it one of its priorities.

In the course of liberating the country from under the German occupation, the actors who managed to survive the nightmare of Second World War began to return to Poland. There was also a large group of them which came from the Soviet Union and settled in Silesia. Those people were the prisoners of ghettos, concentration camps and gulags whose appearance evoked compassion. Nowe Stowo reported that in those beautiful days in May, groups of hungry, haggard, half alive and half dead Jewish survivors were floating about fields and forests, and roads and paths. Hundreds, thousands of Jews, the former condemned people could be encountered on the roads leading from Germany to Poland" ${ }^{42}$

Therefore, the Jewish organisations called upon the Provisional Government of National Unity to provide aid in creating the conditions of a decent life. They believed that only return to normal life would enable the victims to forget the war nightmare. The memorandum proclaimed by the Provincial Jewish Committee of Lower Silesia stated:

Jews who are in a way orphans deprived of relatives and friends wish to forget the tragedy they have lived through and wish to begin to build anew the creative life among their kin, the people who understand one another and who are friendly towards one another. Moving Jews from the places where they have no possibilities to live in a productive way to the places where such possibilities of material and cultural development exist is in the interest of the country and it is an imperative of justice and humanity. ${ }^{43}$

On 16 July 1946, the Congress of the Unions of Jewish Stage Performers was held in Łódź. Then a decision was made to establish two permanent Jewish theatres in Wroclaw and in Łódź. Teatr Dolnośląski (The Lower Silesian Theatre) inaugurated its activities staging the play Chasie di jesome (Chasia An Orphan) by Gordin. The drama which was extremely popular in the mid-war time did not fulfil the expectations of the post-war audience. The successive premieres: Di krojcer sonata [The Kreuzer Sonata] by Gordin, Tewje der milcher [Tevye the Dairyman] by Sholem Aleichem or Di szechite [The Slaughter] by Gordin were also sharply criticised. The creators of the performances were accused of preparing the low level and long outdated shows. The critic of Nowe Życie, using sarcastic words, deemed the repertoire of the Jewish Lower Silesian Theatre inappropriate:

Gordin's dramas are no longer up to date and should not occupy the leading places in the repertoire of our theatres. The good example here is the play Di szechite which has

\footnotetext{
${ }^{41}$ Ibid.

42 J. Egit, "Rok z życia żydowskiego na Dolnym Ślasku," [One year of Jewish life in Lower Silesia] Nowe Życie 1 (1946): 1 .

${ }^{43}$ Gąssowski, Państwowy Teatr, 101.
} 
been recently staged by the Jewish Teatr Dolnośląski. While Krwawy żart [The Bloody Joke] by Sholem Aleichem is still bleeding, Chasie di jesojme should rather make us orphans since it is an anachronism, and even more so is Di szechite. ${ }^{44}$

In this situation, the necessity of reforming the Jewish theatre in Poland was becoming obvious. It was promoted by J. Egit during the conference in Wroclaw devoted to the Jewish culture in Poland. The speaker underlined the merits of the actors who immediately after leaving the camps had understood [...] their role and staged Jewish performances in the most difficult conditions possible" but at the same time he set forth a new task for them to "place theatre on the appropriate level to fulfil the spiritual needs" ${ }^{45}$ of the Jewish nation. Bearing this in mind, he suggested the foundation of the Jewish theatrical studio, employing new, young actors and establishing cooperation with the Polish artistic circles. "The new Polish reality enables" - Egit argued - "the cooperation of the Jewish and Polish institutions and the mutual exchange of cultural values, as well as mutual undertakings of the Polish and Jewish writers and artists. ${ }^{\circ 6}$ The artistic level of the Jewish theatre was sharply criticised by Sara Neszomit, who pointed that the events of the Second World War could not be treated for ever as "the extenuating circumstances since, in this way, the Jewish stage became a substitute of real art." ${ }^{47}$

It was Ida Kamińska who was meant to be a remedy for the poor condition of the Jewish theatre. She came back from the Soviet Union in 1946 and participated in setting the second post-war Yiddish theatre in Lodz. The establishment of this institution was received as a forecast of the revival of Jewish art. The theatre was assigned a very responsible task. Its repertoire was to reflect "pain and longing," "doubts and despair" of the Jewish nation and the past marked with "mass graves and crematoria." 48 It was also to remind of the pre-war artistic life. Therefore, no dramas dubbed "shund" were to be staged. The theatre produced plays devoted to the problems of Jewish tradition, family and religion. The authors of the manifesto published in Nasze Stowo appealed:

Just now, after such a loss of blood of our cultural organism, we cannot afford a doubtful luxury of cheap spectacle, full of theatrical noise mixed with vulgar jokes and satirical songs generating a loud applause of the audience. We have the right to demand from the workers of the Jewish stage to give us such theatre which will arouse interest of the Jewish audience in a better theatre and will raise it to a higher level of understanding and true art." ${ }^{49}$

One of the first work to be staged was Mirele Efros or the Jewish Queen Lear, acclaimed as the masterpiece, while the author was heralded a genius and the reformer of Jewish theatre. The performance directed by Mojżesz Lipman in 1946 in Łódź, had a metaphorical dimension and referred to the tragedy of the Second World War and, above of all, to the situation of Jews. Tragic fate of Mirele Efros symbolised the fate of the Jewish nation which, like her, was subjected to a difficult test,

\footnotetext{
${ }^{44}$ Ibid, 106.

45 Ibid.

46 Ibid.

${ }^{47}$ S. Neszomit, "O inauguaracji sezonu w Teatrze Żydowskim w Łodzi," [The inauguration of the season in the Jewish Theatre in Łódź] Nasze Słowo 15 (1947): 10.

${ }^{48}$ M. M. Borwicz, "Teatr Żydowski zaczyna nowy sezon," [The Jewish Theatre begins a new season] Nowe Stowo 13 (1947): 6.

${ }^{49}$ Neszomit, "O inauguaracji sezonu," 10.
} 
paid with deaths of millions of people. The protagonist of the play, however, severely treated by fate, managed to survive the difficult time without losing the remnants of her human dignity.

Gordin's work in Lipman's adaptation referred also to the post-war reality, being a theatrical commentary to that reality. According to the everlasting principle, the evil was defeated and the good triumphed while the world was slowly waking up to life. The principle message of the Lódź performance was hope that, due to common work and sacrifice, Jews will manage to rebuild "normal" existence and to restore old traditions and customs.

\section{Towards modernity}

An important change of the role of the post-war Jewish theatre in Poland took place in the 1950s. In 1950 theatrical teams from Łódź and Wrocław were nationalized, renamed the Ester Rachel Kamińska State Jewish Theatre, and placed under the direction of Ida Kamińska. Five years later, in 1955 the troupe moved to Warsaw and in this way, Kamińska's greatest dream came true. She was of the opinion that "finding the location in Warsaw, the city sanctified with the martyrdom of Jews, where Jews showed such a great heroism during the ghetto uprising was the matter of national pride." 50

As Małgorzata Leyko observes, Kamińska changed the post-war Jewish theatre forever. It became a modern institution, since it confronted old tradition and the achievements of Jewish artists with contemporary reality. The modern staging, for instance, of Glikl Hameln ${ }^{51}$ [Glikl of Hameln] had quite a relevant meaning although it was a story of a $17^{\text {th }}$ century burgher who fought against all cases of a discrimination of Jews. The production staged in the Jewish Theatre in Warsaw was perceived as a condemnation of the Kielce pogrom ${ }^{52}$ and of the growing anti-Semitic mood in Poland.

Kamińska successfully performed with her team in Warsaw until the mid-1960's. In 1968, due to anti-Semitic campaign held by the Polish government, she decided to emigrate from Poland ${ }^{53}$. Despite these difficulties the State Jewish Theatre did not suspend its activity. It has been continuing its mission of commemorating of pre-war Yiddish tradition until now. A great example of such activity is its last production of Dibuk $k^{54}$. The original text of Szymon An-ski's play is enriched with the testimonies of the Holocaust victims and each element of the production has a symbolic meaning. The stage design imitates Grzybowski Square, the centre of pre-war Jewish quarter and in the former ghetto. The main aim of the spectacle - according to its director - Maja Kleczewska, is to revive the memory of Polish Jews who died during Holocaust. ${ }^{55}$

\footnotetext{
${ }^{50}$ A. Kuligowska-Korzeniewska, "Urodzona w teatrze," [Born in the theatre] Rzeczpospolita 8170 2008), http://www.rp.pl/article/20081117/KULTURA/311179811 (accessed December 27, 2015).

${ }^{51}$ Glikl of Hameln is a play in 4 acts by Max Bauman translated by S. Wajnsztok into Yiddish. Between the wars the role of the main character was successfully performed by Ida Kamińska. Anonymous, "Di greste sensacie in Lublin," [The greatest sensation in Lublin!], Lubliner Shtime 34 (1938): 10.

${ }^{52}$ An act of violence against Jews living in Kielce which took place on 4 July 1946 and resulted in the killing of 42 people.

53 The theatre was renamed "The Ester Rachel Kamińska and Ida Kamińska State Jewish Theater after Kamińska's death.

${ }^{54}$ In Jewish mythology, a dybbuk is believed to be the dislocated soul of a dead person living in the host body until it has accomplished its goal. It is a title a theatrical play which depicts the possession of a young woman by the malicious spirit of her dead fiancé.

${ }^{55}$ P. Guszkowski, "Przesłanie z miejsca przesiąkniętego Dybukami," [An envoy from the place filled with Dybbuks] http://www.pressreader.com/poland/metro0622/20150417/281724088082352/TextView (accessed December 27, 2015).
} 
The victims are like dibukks who cling to us forever. Our Dibukk is about the revival of the Holocaust victims. We give them the right to speak. We bring to the stage the testimony of witnesses, who lived in Warsaw ghetto. ${ }^{56}$

Nowadays the theatrical activity of the Jewish Theatre in Warsaw arouse a lot of controversies. Some of the critics, i.e. Stefan Treugutt, ask if it is still necessary to perform in Yiddish while most members of the audience do not speak this language.$^{57}$ Moreover, it is said that the repertoire of the theatre is outdated because it is not understood by people who are not familiar with Jewish tradition and culture.

\section{Conclusions}

For years, the Jewish theatre in Poland has performed a variety of functions the character of which depended - to a great extent - on the current political and cultural situation in the country. At the beginning, it was perceived as an entirely entertainment institution which addressed its repertoire to a little demanding audience. This theatre was criticised both by rabbis who thought it a sinful place and by Polish and Jewish artistic circles dubbing the Yiddish stage "the jargon theatre."

This situation began to change at the beginning of the $20^{\text {th }}$ century. While Jewish literature began to develop, in particular the Jewish literature in Yiddish, the stage began to be perceived as a vital element of the Jewish national identity. The theatre became an important place of the presentation of political views. And it was this forum where a debate devoted to the place and role of Jews in the Polish culture was held. Among the participants of the discussion were representatives of all parties favouring both cooperation with the Polish creative circles and a separation from them.

In the mid-war period, the Jewish theatre began to be treated as the educational institution since it popularised and disseminated the achievements of Polish Jews. During the war, however, it performed social and entertainment functions.

At present, the Jewish Theatre in Poland plays a very specific role. It became primarily the venue of commemorating the past marked with mass graves and crematoria. It is also one of the most famous research centres of Polish Jewish culture, history, linguistics and literature, gathering and preserving the heritage of the Yiddish language. It has great collections of documents, photographs, recordings, posters, and films in reflecting the culture of Jews in Poland. It's archive, contrary to those of the Jewish Historical Institute in Warsaw or POLIN Museum of the History of Polish Jews, is not only a great resource for the study of East European Jewry, but mainly of Yiddish literature and theatre. Due to initiative of the theatre's headquarters workshops and Yiddish language courses are organized.

Moreover, the Jewish Theatre, as a famous icons of the Jewish community's past, is promoting Jewish culture in Poland and abroad. A great example of such activity is its participation in the Festival of Jewish Culture in Warsaw - "Singer's Warsaw." It is an annual celebration of Jewish culture that has been held in Warsaw since 2004 on the initiative of Gołda Tencer (the president of the theatre). The Festival includes Jewish (both Hebrew and Yiddish) theatre, music, films, exhibits and expositions. It attempts to recreate Jewish culture from the period of interwar Poland, complete with historical buildings and atmosphere. Numerous workshops, discussion groups and seminars are also held on topics related to Yiddish culture.

\footnotetext{
56 Ibid.

${ }^{57}$ Stefan Treugutt, Pożegnanie teatru [Farewell to the theatre] (Warsaw: Errata, 2001), 271.
} 
The Jewish Theatre in Warsaw is an important symbol of an intercultural dialogue. It is also one of a very few institutions in Poland where one can hear the living Jewish word. ${ }^{58}$

\section{References}

Anonymous. "Di greste sensacie in Lublin [The greatest sensation in Lublin!]." Lubliner Shtime 34 (1938): 10.

Anonymous. "Di oyffirung fun H. Leyviks Gojlem in lubliner pojliszn sztot-teater." [The performance of Goylem by H. Leyvik in Polish Municipal Theatre in Lublin] Literarishe Bleter 3 (1928): 61.

Anonymous. "Koło." [Circle] Izraelita 22 (1897): 8.

Anonymous. "Mirele Efros na polskiej scenie." [Mirele Efros on Polish stage] Chwila 3711 (1929, 5.

Anonymous. "Z teatru żydowskiego. Żydowski Król Lir. Obraz życiowy w 4 aktach J. Gordina.” [The Jewish theatre. The Jewish King Lear. The drama in 4 acts by J. Gordin] Nowy Dziennik 171 (1919): 3.

Anonymous. No titled. Izraelita 8 (1886): 60.

Anonymous."Co o nas piszą." [What is written about us] Izraelita 42 (1905): 494.

Borwicz, M. M. "Teatr Żydowski zaczyna nowy sezon.” [The Jewish Theatre begins a new season] Nowe Stowo 13 (1947): 6.

Borzymińska, Zofia; Żebrowski, Rafał, ed., Polski słownik judaistyczny. tom 2 [Polish Judaic dictionary]. Warsaw: Prószyński i spółka, 2003.

Bułat, M. "Es gibt nit beser in der welt...a jidisze mame. Postać matki w wybranych utworach Abrahama Goldfadena. Józefa Latajnera. Izydora Zołotarewskiego i Jakuba Gordina." [There is no one better in the world...Yiddish mother. The firure of mother in selected dramas of Abraham Goldfaden. Józef Latajner. Izydor Zołotarewski an Jacob Gordin] In Nieme dusze?: Kobiety w kulturze jidysz. [Silent Souls?: Women in Yiddish culture], ed. Joanna Lisek, 337-366. Wrocław: Wydawnictwo Uniwersytetu Wrocławskiego, 2010.

Chan, Z. "Der erszter Hamlet af der jidisze bine. R. Zaslawski in Adlers teatrer." [The first Hamlet on the Yiddish stage. R. Zasławski in Adler's Theatre] Lodzer Tageblat” 120 (1913): 4.

Chan, Z. "Hamlet af jidisz." [Hamlet in Yiddish] Lodzer Tageblat 118 (1913): 2.

Czerwiński, H. “Szmira.” [Kitsch] Gazeta Żydowska 107 (1941): 3.

Egit, J. "Rok z życia żydowskiego na Dolnym Ślasku." [One year of Jewish life in Lower Silesia] Nowe Życie 1 (1946): 1.

Ego. "Przed premjerą Miry Efros. Rozmowa z Andrzejem Markiem." [Before the premiere of Mirele Efros. An interview with Andrzej Marek] Republika 169 (1929) 4.

Engelking, Barbara; Leociak, Jacek. Getto warszawskie. Przewodnik po nieistniejacym mieście [The Warsaw Ghetto: A Guide to the perished City] Warsaw: IFiS PAN, 2001.

F.O. "Z Teatru Bagatela." [From the Bagatela Theatre] Gtos Narodu 53 (1930) 4.

Frenkiel, J. "Teatr i inna działalność artystyczna w getcie łódzkim." [Theatre and other artistic activity in the Lódź ghetto] In Łódzkie sceny żydowske [Lodz Jewish scene], ed. Małgorzata Leyko, 91-121. (Łódź: Wydawnictwo Uniwersytetu Łódzkiego, 2000

Gąssowski, Sz. "Teatr w latach 1944-1949." [Theatre in years 1944-1949] In Państwowy Teatr Żydowski im. Ester Rachel Kamińskiej [The Ester Rachel Kamińska State Jewish Theatre], ed. idem, 99-122. Warsaw: PWN, 1995.

\footnotetext{
${ }^{58}$ D. Karpiuk, "Niepamięć,” [Nomemory] Newsweek 19 (2015): 78.
} 
Guszkowski, P. "Przesłanie z miejsca przesiąkniętego Dybukami." [An envoy from the place filled with Dybbuks] http://www.pressreader.com/poland/metro0622/20150417/281724088082352/TextView (accessed December 27, 2015).

Hernik-Spalińska, Jagoda. Życie teatralne $w$ Wilnie podczas II wojny światowej [Theatre life in Vilnius during World War II] (Warsaw: Instytut Sztuki Polskiej Akademii Nauk, 2005.

J.Z. "Nauka i literatura. Więcej godności. poeto!.” [Science and literature. More dignity. poet!] Myśl Narodowa 19 (1934): 286.

Kahan, L. "Hamlet ojffirung in Scala teater." [The performance of Hamlet in the Scala theatre] Lodzer Tageblat 292 (1913): 4.

Karpiu, D. "Niepamięć." [Nomemory] Newsweek 19 (2015): 78.

Kozłowska, Mirosława. Wilno teatralne [Theatrical Vilnius] (Warsaw: Ogólnopolski Klub Miłośników Litwy, 1998.

Kuligowska-Korzeniewska, A. "Urodzona w teatrze.” [Born in the theatre] Rzeczpospolita 81702008 , http://www.rp.pl/article/20081117/KULTURA/311179811 (accessed December 27, 2015)

Mukduni, A. “A derklerung.” [Explanation] Najes Lodzer Morgenblatr 126 (1913): 3.

Najman, J. M. “Der gojlem po polsku.” [Golem in Polish] Hajnt 128 (1928): 9.

Neszomit, S. "O inauguaracji sezonu w Teatrze Żydowskim w Łodzi." [The inauguration of the season in the Jewish Theatre in Lodz] Nasze Stowo 15 (1947): 10.

Pilawa, T. "Mirla Efros. sztuka w 4 aktach J. Gordina." [Mirele Efros. play in 4 acts by J. Gordin] Dziennik Wileński 287 (1929): 10.

Sakowska, Ruta. Ludzie z dzielnicy zamkniętej - z dziejów Żydów w Warszawie w latach okupacji hitlerowskiej: październik 1939-marzec 1943 [People from the closed district - from the history of Jews in Warsaw during the Nazi occupation: October 1939-March 1943] Warsaw: PWN, 1993.

Shmeruk, Chone. Peretses yiesh-vizye [Peretz's vision of despair]. New York: YIVO, 1971.

Steinlauf, Michael. Theatre. http://www.yivoencyclopedia.org/printarticle.aspx9id=298\&print=auto (accessed September 30, 2015).

Steinlauf, Michael. Polish-Yiddish theater: the case of Mark Arnshteyn: a study of the interplay among Yiddish, Polish, and Polish-language Yiddish culture in the modern period. Ann Arbor: UMI Dissertation Service, 1988.

Treugutt, Stefan. Pożegnanie teatru [Farewell to the theatre] Warsaw: Errata, 2001.

Turkow, J. "Di 'kemfer' far jidiszer kultur." [The fighter about Yiddish culture] Literarisze Bleter 36 (1929): $1-2$

Turkow, J. "Jidisz teatre on jidisz." [Yiddish theatre about Yiddish] Literarisze Bleter 33 (1929): 641

Zastępca. "Scena polsko-żydowska.” [Polish-Jewish stage] Nasz Przegląd 203 (1929): 6.

Zylbercweig, Z. "Leon Kobrin." In Leksikon fun jidishn teater vol. 4 [Lexicon of Yiddish theatre], ed. Zalmen Zylbercweig, 2962-3044. New York: Jidishe aktiorn jiunie in Amerike, 1963.

Zylbercweig, Z. "Rudolf Zaslawski." In Leksikon fun jidishn teater vol. 1 [Lexicon to Yiddish theatre], ed. Zalmen Zylbercweig, 751-752. New York: Jidishe aktiorn jiunie in Amerike, 1931.

Zylbercweig, Z. "Jacob Gordin." In Leksikon fun jidishn teater vol. 1 [Lexicon to Yiddish theatre], ed. Zalmen Zylbercweig, 392-461. New York: Jidishe aktiorn jiunie in Amerike, 1931. 